\title{
Anatomical Study of Male Reproductive Organs of the Indonesian Short-Nosed Fruit Bat (Cynopterus titthaecheilus Temminck, 1825)
}

\author{
Anisatuzzahro ${ }^{1}$, Muhammad Jafar Luthfi ${ }^{2}$ \\ ${ }^{1}$ SDI Ma'arif Tawangsari Garum, \\ Kompleks Perguruan Ma'arif Garum, Tawangsari, Garum, Tawangsari, Garum, Blitar, East Java 66182, Indonesia \\ ${ }^{2}$ Biological Education Department, Faculty of Science and Technology, UIN Sunan Kalijaga \\ J1. Marsda Adisucipto 55281 Yogyakarta, Indonesia \\ Author correspondency: \\ anisatuzz@gmail.com ${ }^{1}$
}

\begin{abstract}
Bats are one of the mammals of Chiroptera order. Chiroptera Order has two sub-orders, Megachiroptera and Microchiroptera. One of the species of Megachiroptera is Cynopterus titthaecheilus (C. titthaecheilus). Local name for C. titthaecheilus is the Indonesian short-nosed fruit bat. Characteristics of $C$. titthaecheilus are dark brown body hair and no tragus in the ear. Population of $C$. titthaecheilus in Indonesia are relatively abundant, but research about anatomy of male reproduction organs of this species is still rare. The purpose of this study was to determine the anatomical features of male $C$. tittahecheilus reproductive organs. Observations of macroscopic anatomy include observation of morphology, size, weight and volume of penis, testiscle, epididymis, vas defferens, prostate and seminal vesicles. Observation on microscopical anatomy of male reproduction organ is using histological slide preparations stained by Hematoxylin-Eosin.
\end{abstract}

Keywords: Anatomy; Histology; Cynopterus titthaecheilus; Male reproductive organ.

\section{INTRODUCTION}

The Indonesian short-nosed fruit bat is the local name of the fruit-eating bat of Cynopterus titthaecheilus species. Bat is living in many areas or islands in Sumatra, Java, and Nusa Tenggara. The Cynopterus titthaecheilus species are belonging to sub-order Megachiroptera of Chiroptera Order (Maharadatunkamsi, 2011). Suyanto (2003) stated that bats consist of several species and occupy a second position in number of species related to the population of the mammalian class after rodentia. The majority of these bats live in tropical and semitropical areas. There are 4000 species of mammals, 963 of them are bat species. This species has an important role in the ecosystem as controlling insect pest agent, pollinators of flowers and grain spreaders and guano producers that can be used as fertilizer. Its ability to fly and cruising are as far as about $20 \mathrm{~km}$. Bats that live in Asia and Africa have small body size (Anonim, 1997). Bats live and actively searching for food only at night because bats are very sensitive to dehydration. In the daylight, bat hanging upside down. These animals are nocturnal and therefore require a roosting area during the day. There were also crepuscular bats, they go out from cave during afternoon till dark (Prasetyo et al., 2011).

There are two factors that can affect the survival of bats, namely external and internal factors. Outside factors consist of environment, food and photoperiodicity, whereas inner factor consists of nerves and hormones. Photoperiodicity has a serious impact on the size of reproductive organs, the more exposed to the sun exposure the better effect to reproductive organs (Isnaeni, 2006).

Morphology of male reproduction organs of bats differs during hibernation and active period. The testis volume is smaller when it comes to hibernation. At the time of hibernation no spermatogenesis occurs because the body temperature and environment are unstable and incompatible (Entwistle et al., 1998).

\section{MATERIALS AND METHODS}

This research was carry on for 3 months at Zoological Laboratory in Integrated Laboratory of State Islamic University Sunan Kalijaga Yogyakarta, and Pathology Laboratory of Veterinary Center, Wates, Yogyakarta.

The equipments used in this study were a set of surgical instruments (consisting surgical scissors, tweezers, razors and scalpels), flacon bottles, surgical or paraffin box, needles, digital cameras, ruler, embedding proccessor, tissue proccessor, embedding cassette, base mold, staining jar, incubator, microtome, slide glass, cover glass, toothpick, mask, gloves and optilab ${ }^{\circledR}$ microscope.

Materials used in this study were HVS paper, ether or chloroform solution, $0.9 \% \mathrm{NaCl}$ physiological solution, fixative bouin, alcohol, hematoxcylin-eosin 
dye, albumin, xylol, distilled water, canada balsam, paraffin.

In this study, the test animals were ten fruit-eating bat (Cynopterus titthaecheilus) of with a weight size ranging from $78.88 \pm 3.88$ grams. Objects observed include testes, epididymis, penis, prostate, vas deferens, seminal vesicles and bulbourethral gland.

Reproductive organs of test animals were dissect and then put in flacon bottles containing bouin for overnight. The next step is dehydration using stratified alcohol, clearing using xylol and infiltration using paraffin. The next step were embedding and cutting block of paraffined organs. Observations were done using Optilab $^{\circledR}$ microscope with magnification of 40,100 and 400 times, and taking picture for each sample.

\section{RESULTS AND DISCUSSION}

Description of Macroscopic Anatomy of Male $C$. titthaecheilus Reproductive Organs

A common characteristic of $C$. titthaecheilus is dark brown hair color on its entire body and light brown in the neck area. Determination of adolescent and adult bats is by looking at the color of the hairs that found on the neck. The darker the brown color of hairs, the more mature the bat. Bat tail is not long. The ears are small and slightly elongated. The shape of the face is rather tapered forward (Figure 1).

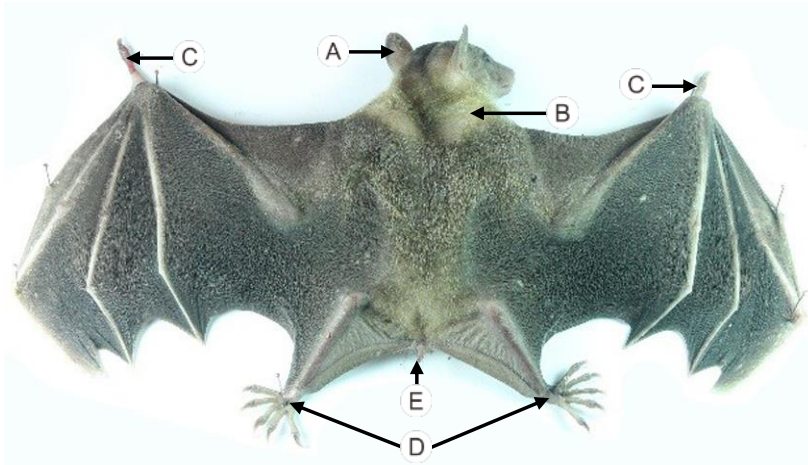

Figure 1. Morphology of bat C. titthaecheilus. (A). Ears are slightly tapered; (B). Hair on the neck; (C). Modification of thumb; (D). Clawed toes; (E) Short tail.

Testes of $C$. tithaecheilus species have a yellowish white color and there are irregular streaks of blood vessels (Figure 2). The position of testes of $C$. titthaecheilus species remains in the abdomen. This is similar to that of the Rhinipoma kinneari Wroughton species (Singwi \& Lall, 1983). In other mammals such as mice and squirrels, the testes are located in the outer body in scrotum. Visible ducts are attached to the testes (Figure 3). This duct is called epididymal duct.

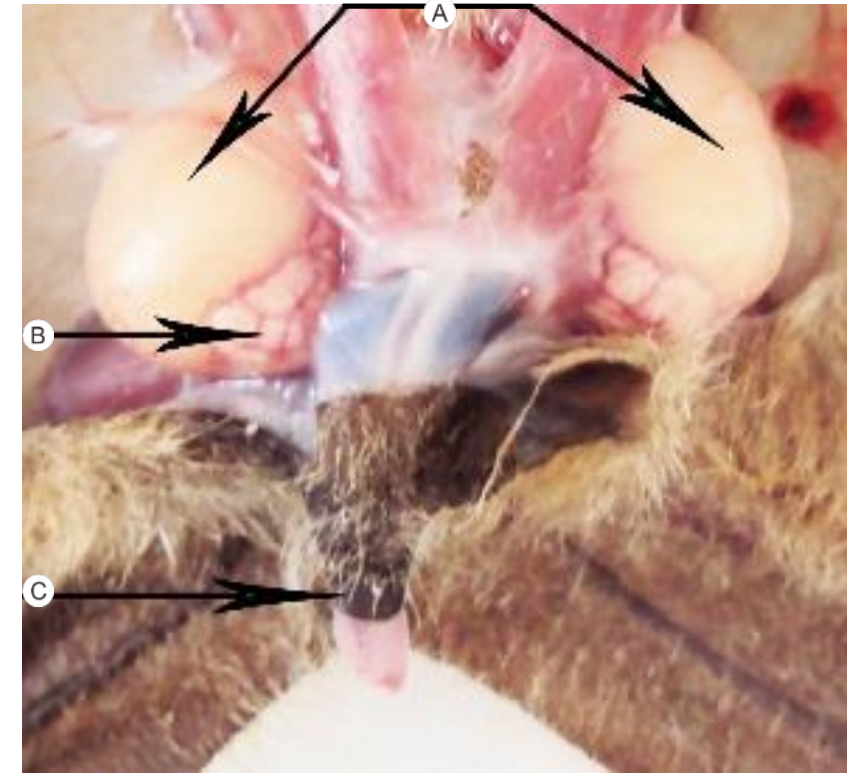

Figure 2. Reproductive organs seen from the outside after the integument is removed. (A). Testes; (B). epididymis; (C). Penis.

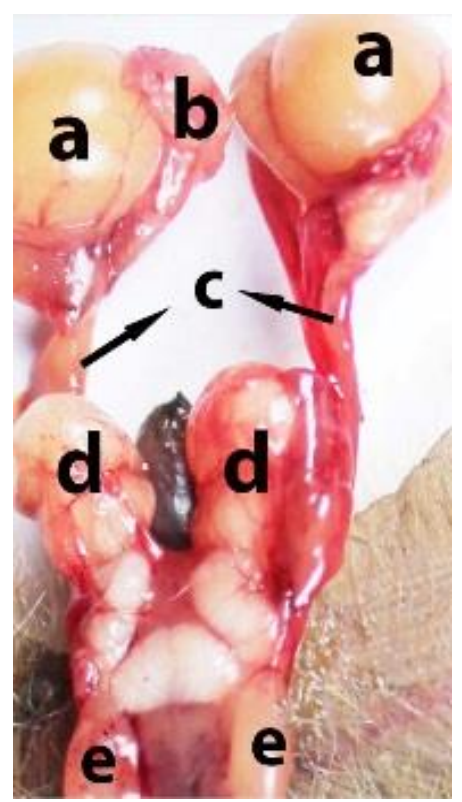

Figure 3. Accessory glands of C. titthaecheilus. (a). Testis; (b). Epididymis; (c). Vas deferent vas; (d). Seminal vesicles; (e). Prostate gland.

Penis is located in the outside of body cavity, like mammals in general. Penis is an external reproduction organ because its location is outside the body.

\section{Description of Microscopic Anatomy of Male $C$.} titthaecheilus Reproductive Organs

Histological or microscopic anatomical characters of $C$. titthaecheilus reproductive organs are not much different from other Bats. In general, testes have functions as a reproductive organ and regulator of the hormonal 
system. Testes of $C$. titthaecheilus are protected by 2 layers, including tunica vaginalis which is the outermost layer and tunica albuginea which lies beneath tunica vaginalis (Figure 4). The tunica albuginea is a layer formed from connective tissue. In tunica albuginea there are septa that form some lobules. The lobule is called the testicular lobule, where in the lobule there is a long that forms the sperm called the seminiferous tubule (Figure $5)$.

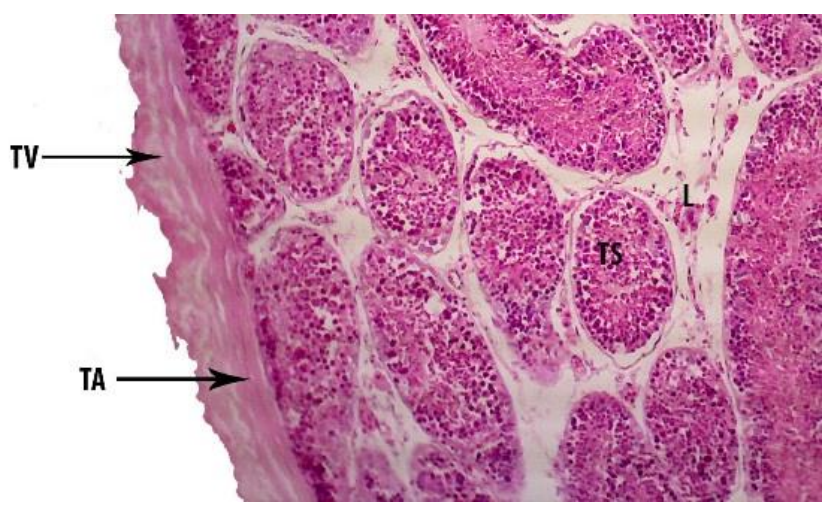

Figure 4. Cross-section of testes C. titthaecheilus with HE. 100x magnification. (TS). Seminiferous tubule; (L). Leydig cells; (TA). Tunica albuginea; (TV) Tunica vaginalis.

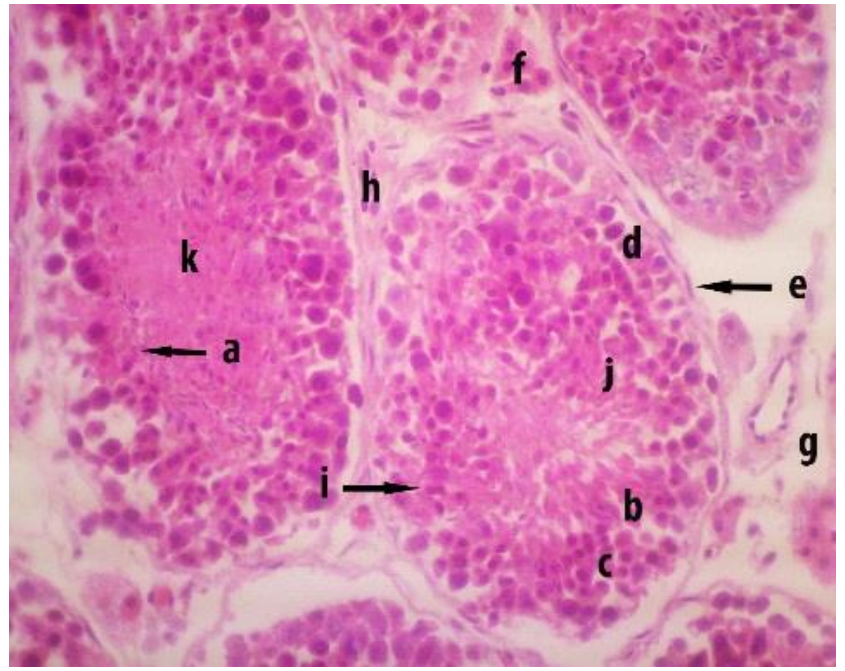

Figure 5. Cross-sectional of seminiferous tubule of C. titthaecheilus with HE. 400x magnification. (a). Sperm; (b). Secondary spermatocytes; (c). Primary spermatocytes; (d). Spermatogonia; (e). Thin myoid cells; (f). Leydig cells; (g). Connective tissue; (h). Fibroblast layer; (i). Sertoli cells; (j). Spermatids; (k). Lumen.

Seminferuos tubule is a canal that has an arch-shaped and forming a coil in a lobule. Intersitial space between the seminiferous tubule fills with connective tissue and Leydig cells that play a role in producing testosterone hormone. In seminiferous tubule occurs a process of sperm production called spermatogenesis.
Spermatogenesis involves a large number of epithelial germ cells or epithelial cells of the germ. Germinal epithelial cells consist of spermatogonia, spematocytes and spermatids. The position of the spermatogonia are in the basal layer of the seminiferous tubule (Figure 5).

Sometimes these secondary spermatocyte cells are rarely found because the transition of development from primary spermatocytes to secondary spermatocytes is so rapid that it is rather difficult to observe (Dreef et al., 2007).

Process of sperm maturation will occur in the duct of epididymis. Epididymis is a duct that delivers spermatozoa to the next duct called vas defferens or commonly called vas deferens.

Epididymal duct consists of several layers. The outermost layer is composed of smooth, circular muscles, beneath it there is a network of semi-shaped columnar epithelium with stereocillia. The tissue of tunica vaginalis (Figure 6) acts as a protective layer.

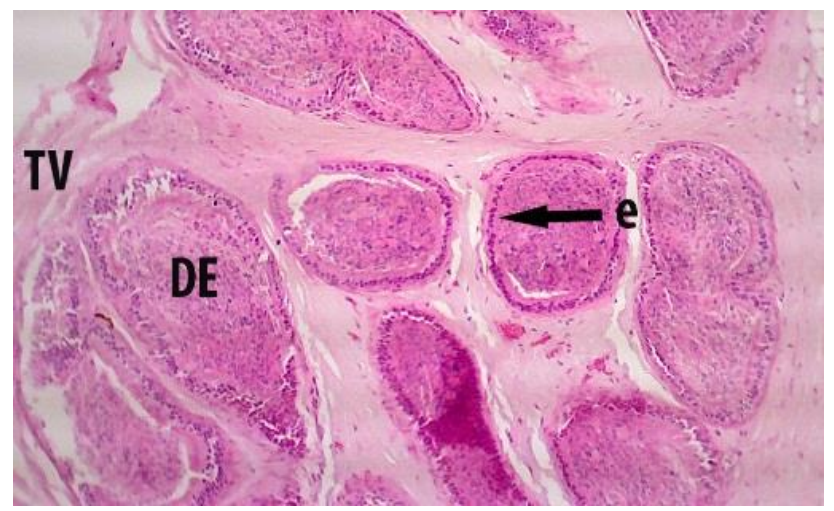

Figure 6. Cross sectional of epididymis of C. titthaecheilus with HE. 100x magnification. (ED). Epididymal duct; (e). Semi-shaped columnar epithelium with long stereosilia; (TV). Tunica vaginalis.

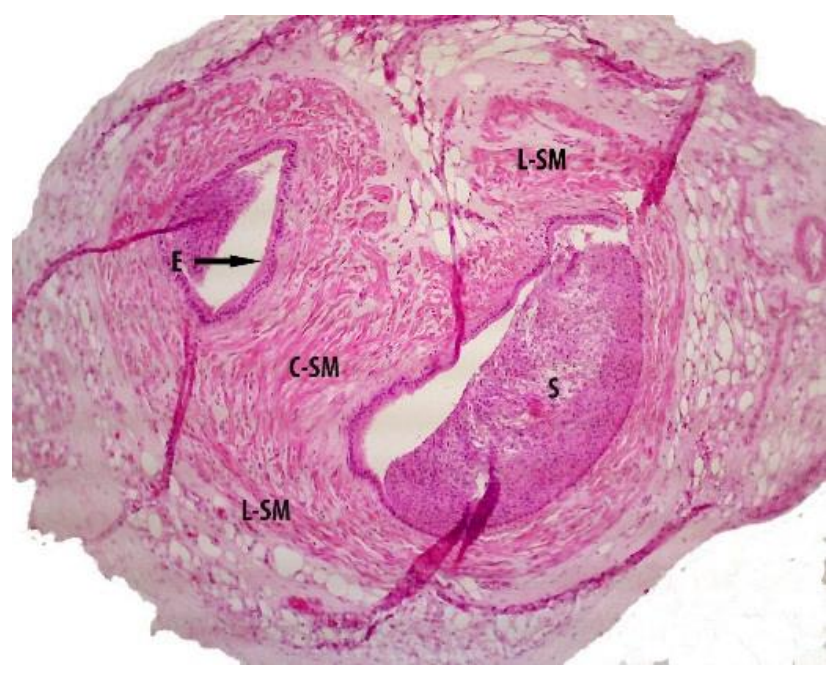

Figure 7. Cross-sectional of vas deferens of C. titthaecheilus stain with HE. 100x magnification. (C-SM). Circular muscle; (E). Epithelial layer; (L-SM). Longitudinal smooth muscle; (S). lumen containing sperm. 
Sperm movement is assist by stereocillia that move unidirectional. Sperm will move through the epididymis to the vas deferens by peristaltic contraction of smooth muscle tissue connective wall (Sinaga, 2011). Vas deferens is also known as ductus deferens. Vas deferens is a duct that bring sperm to the urethra. This duct is surrounded by a thick layer of muscle. There is a longitudinal smooth muscle and smooth circular muscle (Figure 7). There is a layer of epithelium that surrounds the lumen containing sperm. Lumen in the deferens duct is narrower than lumen in the duct of the epididymis.

There are accessory glands in this species such as seminal vesicles, prostate, and bulbouretralis. This seminal vesicle is one of the accessory glands of the male mammal. Between species threre may have different morphological or anatomical forms of this seminal vesicle gland (Hafez, 2000). The seminal vesicle gland consists of a mucous that characterized the duct. The mucous occupies almost all of the lumen. This gland is surrounded by a layer of smooth muscle in its outermost. The lumen is in the central part surrounded by the ducts.

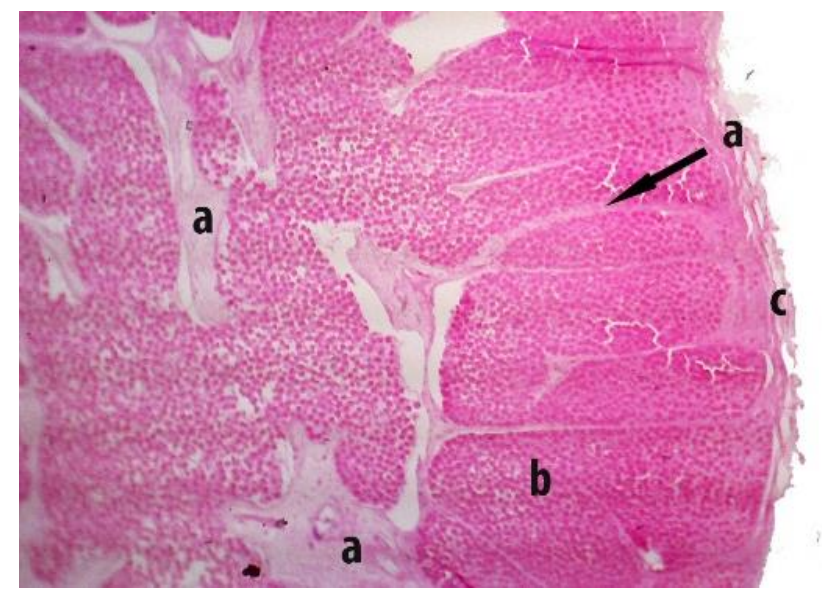

Figure 8. Cross-sectional of seminal vesicle gland of C. titthaecheilus stained with HE. 400x magnification. (a). Lumen; (b). mucous; (c). smooth muscle.
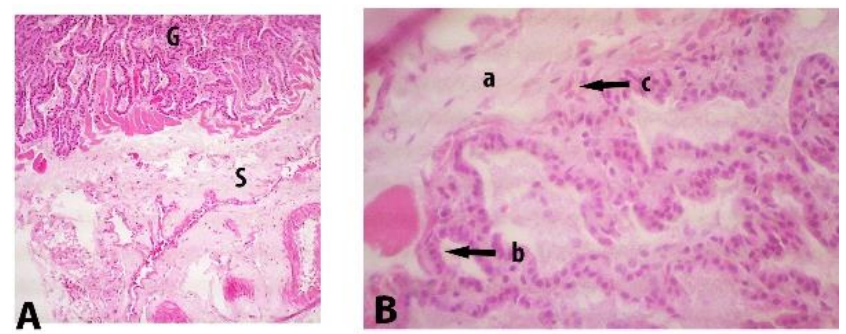

Figure 9. Cross-sectional of prostate gland of C. titthaecheilus stained with HE. 100x magnification (A) and 400 times magnification (B). (a). Plain muscle; (b). Columnar epithelium; (c). Lamina propia; (G). Tubuloalveolar gland; (S). Solid fibromuscular stroma.
In addition to seminal vesicle glands, the second gland is prostate gland. In general, the results of previous studies in the prostate gland have solid fibromuscular stroma. Most of the prostate gland is occupied by the tubulo-alveolar glands. Tubulo-alveolar gland is a form of secretion that is a combination of tubular forms and alveolar (like grape). In this tubuloalveolar gland there is a stratified columnar epithelial cell. In addition there is also a lamina propia that surrounds the epithelial cells. As well as the smooth muscle tissue surrounding the lamina propia.

The third accessory gland after seminal vesicle and prostate gland is the bulbourethral gland or commonly known as Cowper's gland. In general, this gland has a function as a secrete producer therefore called exocrine gland (Wahyuni et al., 2013). Observation of microscopic anatomy from the bulbourethral gland of $C$. titthaecheilus shows that in this gland there were tubuloalveolar glands that occupy most of the bulbourethral gland space. In tubulo-alveolar gland, a columnar epithelial cell lies at the edge of the tubulo-alveolar lobe (Figure 10). The smooth muscle tissue seen around the tubulo-alveolar gland and the secretions inside the tubulo-alveolar lumen appear on the bulbourethral gland preparations.

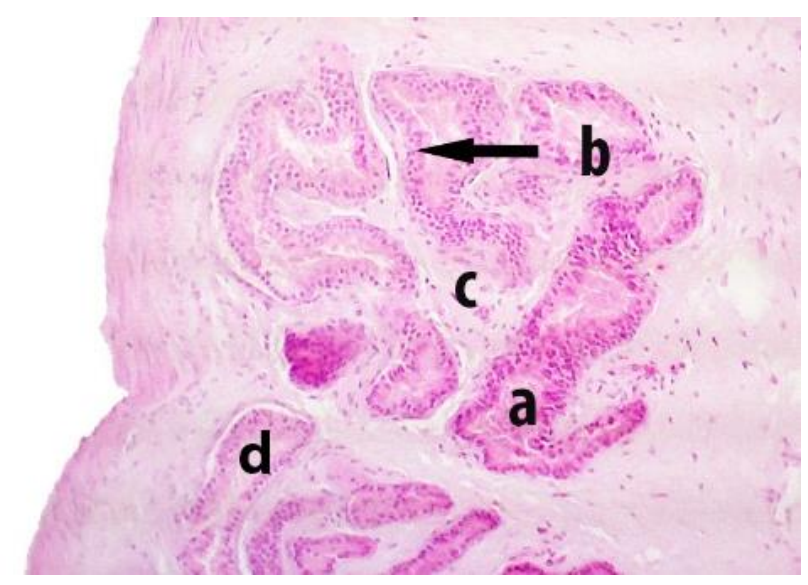

Figure 10. Cross-sectional of bulbourethral gland of C. titthaecheilus stained with HE. 100x magnification. (a). Tubulo-alveolar glands; (b). Columnar cells of the lining; (c). Smooth muscle; (d). Secretions in the lumen of the gland.

Penis is a copulation organ for mammals that has the function of transferring sperm from the male reproductive tract to the female reproductive tract. In this microscopic anatomy there is a major component found in the penis namely two corpus cavernosun and one corpus spongiosum and penis urethra. As a major component, corpus cavernosum and corpus spongiosum is an erectile network. 


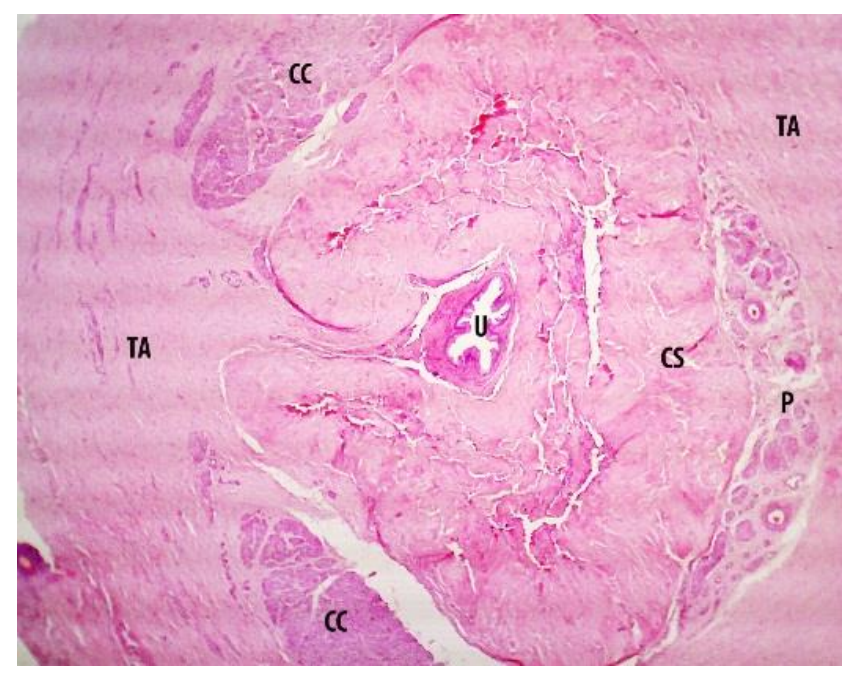

Figure 11. Cross-sectional of penis of C. titthaecheilus stained with HE. 40x magnification. (CC). Corpora cavernosa, (CS). Corpus spongiosum; (P). Veins; (TA). Tunica albuginea; (U). Urethra.

Cynopterus titthaecheilus penis do not have fibrocartilago and os penis or baculum tissue (Figure 11) which are usually present in Chiropteran mammals. Baculum or os penis has a function as a supporting assistance to penetrate the vaginal canal of female mammal animals as well as improve transport and deposition during mating (Vamburkar, 1957 in Danmaigoro, 2014).

\section{CONCLUSION}

Species of fruit-eating bats (Cynopterus titthaecheilus) has no baculum (os penis and fibrocartilago). The mature animal of this species do not descent its testes to scrotum, instead of retain in body celoem. The testes and its accessories gland have similar histological structure to other mammal in general.

\section{REFERENCES}

Anonim.1997. Bat facts and amazing trivia. Beautifortia, 40: 111177.

Dreef, H.C., Van Esch E., De Rijk E.P.C.T. 2007.Spermatogenesis in cynomolgus monkey (Macaca fascicularis): a practical guide forroutine morphological staging. ToxicolPathol, 35: 395-404.

Entwistle, A.C., P.A. Racey \& J.R. Speakman. 1998. The Reproductive and determination of sexual matury in male brown long-eared bats, Plecotus auritus (Chiroptera: Vespertilionidae). (Abstract) Journal of Zoology, 244:63-70.

Hafez, E.S.E. 2000. Reproduction in Farm Animals. Hafez (7 th ed.). Lippincott William \& Wilkins. A Wolter Kluwer Company.

Isnaini, Wiwi. 2006. Fisiologi Hewan. Yogyakarta: Penerbit Kanisius.

Maharadatunkamsi. 2011. Profil Fauna Mamalia Kecil GununG. Slamet. Jurnal Biologi Indonesia, 7 (1): 171-185.

Prasetyo, Pandam Nugroho., S. Noerfahmy \& H.L. Tata. 2011. Jenis-Jenis Kelelawar Khas Sumatera. World Agroforestry Centre - ICRAF, SEA Regional Office: 75.

Sinaga,H.2011.http://repository.usu.ac.id/bitstream/123456789/25 485/4/Chapter\%20II.pdf/ Retrieved at 07/08/2015 time 04.29 WIB.

Singwi M.S. \& Lall S.B. 1983. Spermatogenesis in the nonscrotal bat-Rhinopoma kinneari Wroughton (microchiroptera: mammalia). (Abstract). 116 (3): 136-145.

Suyanto, A. 2003. Kelelawar Pemakan Buah dan Taman Nasional Gunung Halimun. Zoo Indonesia, 5 (2): 31-40.

Vamburkar, S. 1957. The male genital tract of the Indian megachiropteran bat Cynopterus sphinx gangeticus Anderson. (Summary) Proceeding of the Zoological Society of London, 130: (57-77).

Wahyuni, S., L.E.M Manik., Srihadi A., M. Agil., T.L Yusuf., Hamny., I Ketut Mudite A. 2013. Morfologi Kelenjar Aksesori Kelamin Muncak (Muntiatus muntjak muntjak) Jantan. ACTA Veterinaria Indonesia, 1 (2): 84-93. 
THIS PAGE INTENTIONALLY LEFT BLANK 